\begin{tabular}{l}
$\begin{array}{l}\text { A C T A I C H T H Y O L O G I C A } \\
\text { Vol. XXIII, Suppl. }\end{array}$ \\
\hline
\end{tabular}

Andrzej SOBOCINSKI, Krzysztof RADZIUN

\title{
PRELIMINARY OSTEOLOGICAL STUDIES ON THE ARCTIC CHARR, SALVELINUS ALPINUS (L., 1758) FROM THE HORNSUND REGION (SPITSBERGEN)
}

\section{WSTEQPNE BADANIA OSTEOLOGICZNE GOLCA SALVELINUS ALPINUS (L. 1758) Z REJONU HORNSUNDU (SPITSBERGEN)}

\author{
Faculty of Marine Fisheries and Food Technology, \\ Academy of Agriculture, \\ Szczecin, Poland
}

\begin{abstract}
A preliminary osteological analysis of 48 individuals of the Arctic charr, Salvelinus alpinus (L., 1759) was performed within the framework of a comprehensive study of the species in the area of Hornsund (Vest Spitsbergen). The Arctic charr in the area were found to have 63-67 vertebrae (64.3 on the average). Variability of the size and shape of skull bones was subject to a preliminary analysis in terms of their diversification. The considerable differences in the appearance of the bones could have been caused, apart from the sexual dimorphism, by a considerable variation in length and age of the individuals examined. Malformations in the backbone and skull bones were observed in the sample.
\end{abstract}

\section{INTRODUCTION}

Osteology of the salmonid genus Salvelinus has been worked out quite extensively, both at the single species level and comparatively (against other salmonids). Osteological analyses were used by numerous workers in their taxonomic and phylogenetic studies (Norden, 1961; Rešetnikv and Savvaitova, 1962; Quadri, 1974; Cavender, 1980; Medvedeva and Savvaitova, 1980; Glubokovskij and Čerešnev, 1981). In morphological analyses of taxonomic units, attention is paid to a high variability 
of osteological characteristics within a species, and even within populations (Rešetnikov and Savvaitova, 1962; Medvedeva and Savvaitova, 1980; Vasileva, 1981; Picugin, 1983).

Preliminary osteological analyses, presented in this work, were performed within the framework of a comprehensive study on biology of the Arctic charr, Salvelinus alpinus (L., 1758) from water bodies in the area of Hornsund (Vest Spitsbergen).

\section{MATERIAL AND METHODS}

Analyses were made on a total of 48 individuals, 2 of which were caught in Lake Revvatnet, 7 in River Revelva, and 39 in Lake Svartvatnet. The sample contained 20 males, 27 females, and one individuals of unidentified sex. The fish total length ranged from $34.0-60.7 \mathrm{~cm}$. To count the vertebrae, all the individuals were X-rayed. Skulls were soaked first in water and then in $1-2 \% \mathrm{KOH}$; individual bones were cleaned and photographed. The bone nomenclature used follows that of Norden (1961).

\section{RESULTS AND DISCUSSION}

Vertebrae were counted on X-ray images (Fig. 1) and the results are summarized in Table 1. The average vertebra count of Salvelinus alpinus from the area of Hornsund is 64.3 (the range is 63-67). Other values have been reported for different populations. Vasileva (1981) counted 59-66 vertebrae in the Kola Peninsula population, while Mina (1962) found 60-68 vertebrae in the Arctic charr from the River Lena delta. Cavender (1980) quotes a mean of 63.2 vertebrae (the range of 61-67) in

Table 1

Vertebrae counts in the Arctic charr, Salvelinus alpinus in the area of Hornsund

\begin{tabular}{l|c|c|c|c}
\hline \multicolumn{1}{c|}{ Capture site } & $\mathrm{n}$ & $\begin{array}{c}\text { Vertebrae } \\
\text { count }\end{array}$ & $\overline{\mathrm{x}}$ & S.E. \\
\hline Lake Revvatnet & 2 & 64 & 64.0 & 0.00 \\
River Revelva & 7 & $64-66$ & 64.4 & 0.38 \\
Lake Svartvatnet & 38 & $63-67$ & 64.3 & 0.16 \\
\hline Hornsund & 47 & $63-67$ & 64.3 & 0.13 \\
\hline
\end{tabular}




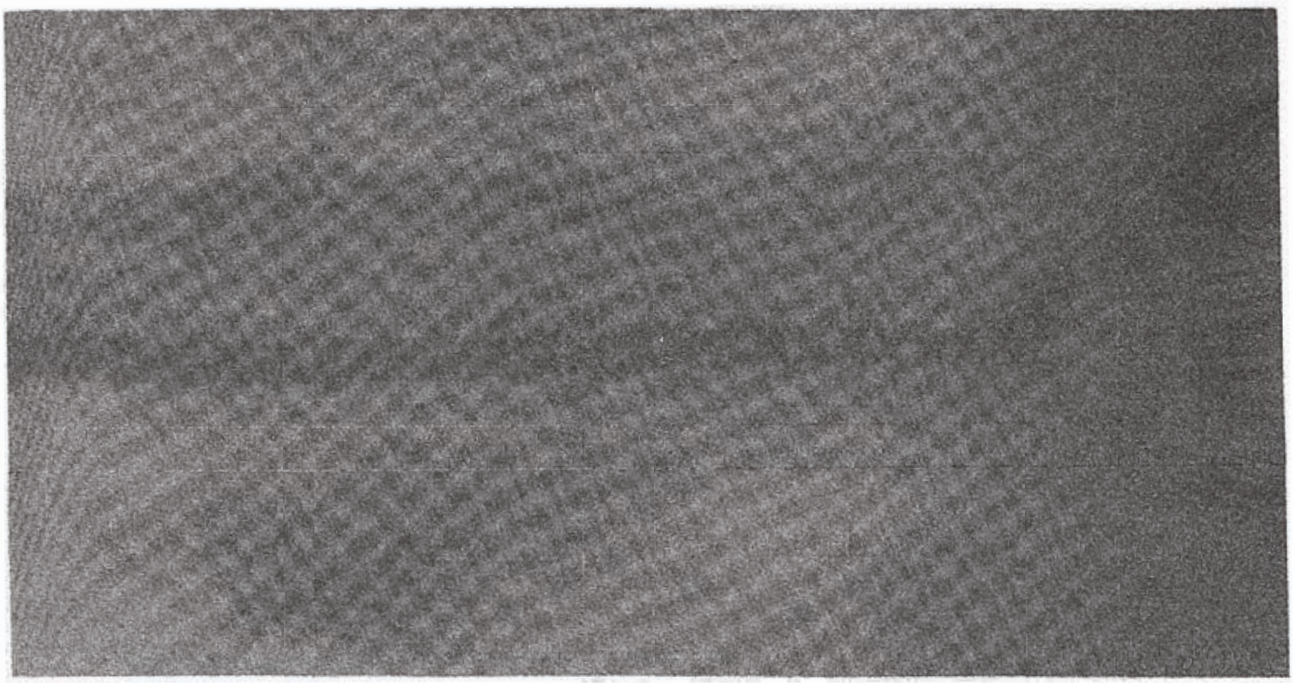

Fig. 1. A fragment of backbone X-ray image of Arctic charr (S. alpinus) from the area of Hornsund

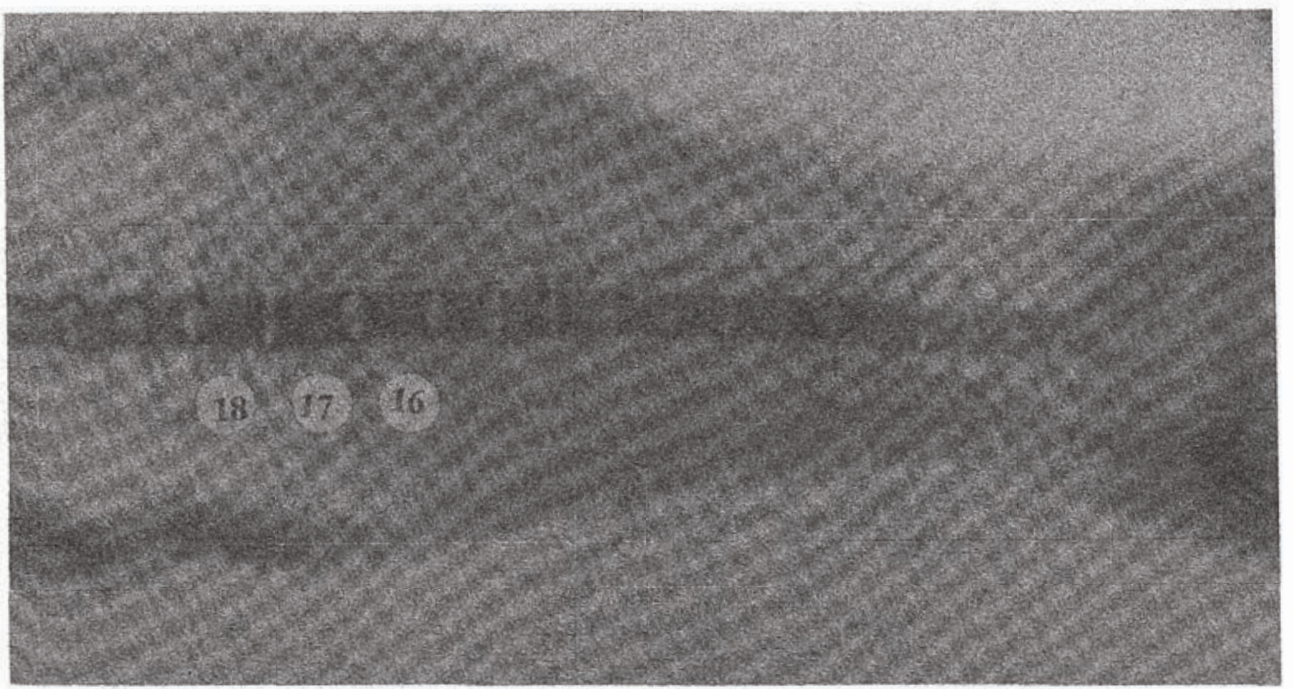

ig. 2. A fragment of Arctic charr X-rayed backbone with malformations (altered vertebrae 16,17, and 18) 


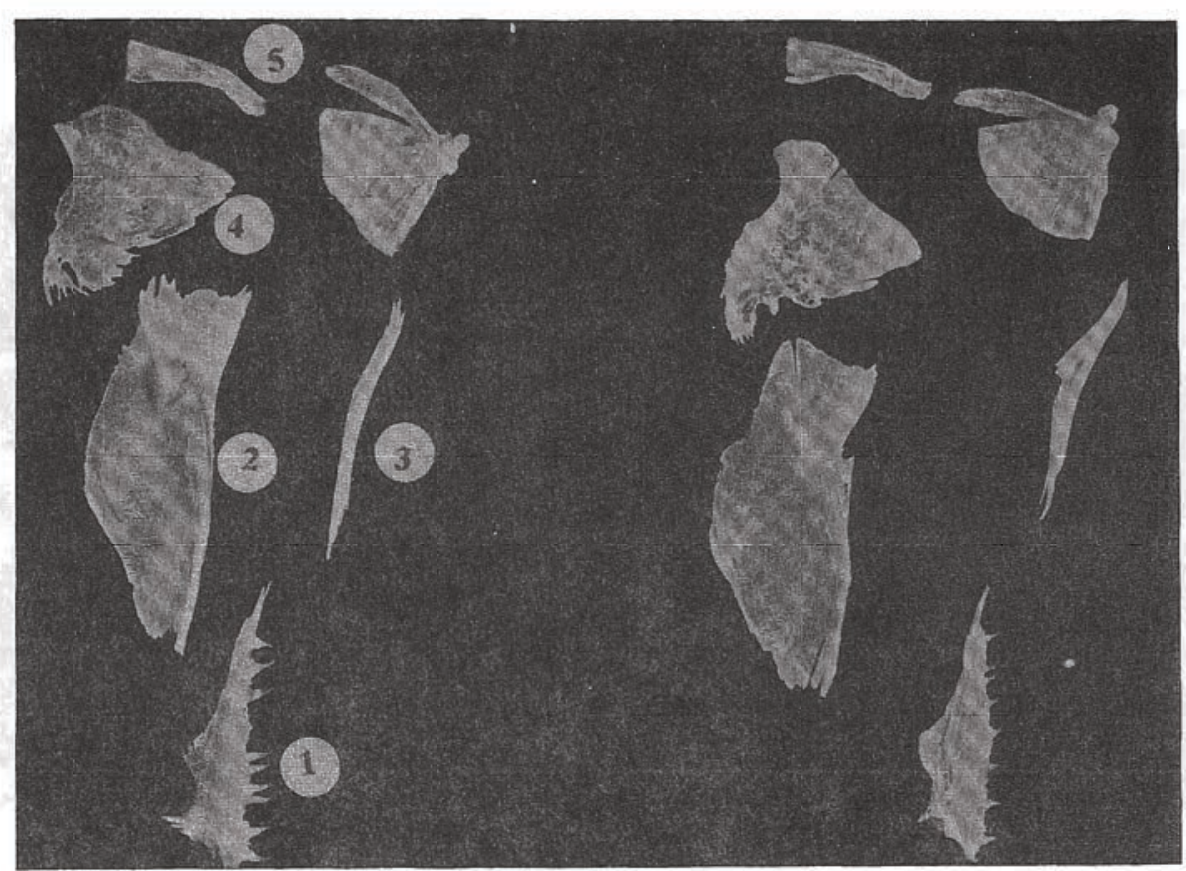

Fig. 3. Some skull bones of Arctic charr (S. alpinus) from the area of Hornsund: 1, palatine; 2, mesopterygoid; 3 , ectopterygoid; 4 , metapterygoid; 5 , symplectic; 6 , quadrate. Male bones to the left; female bones to the right

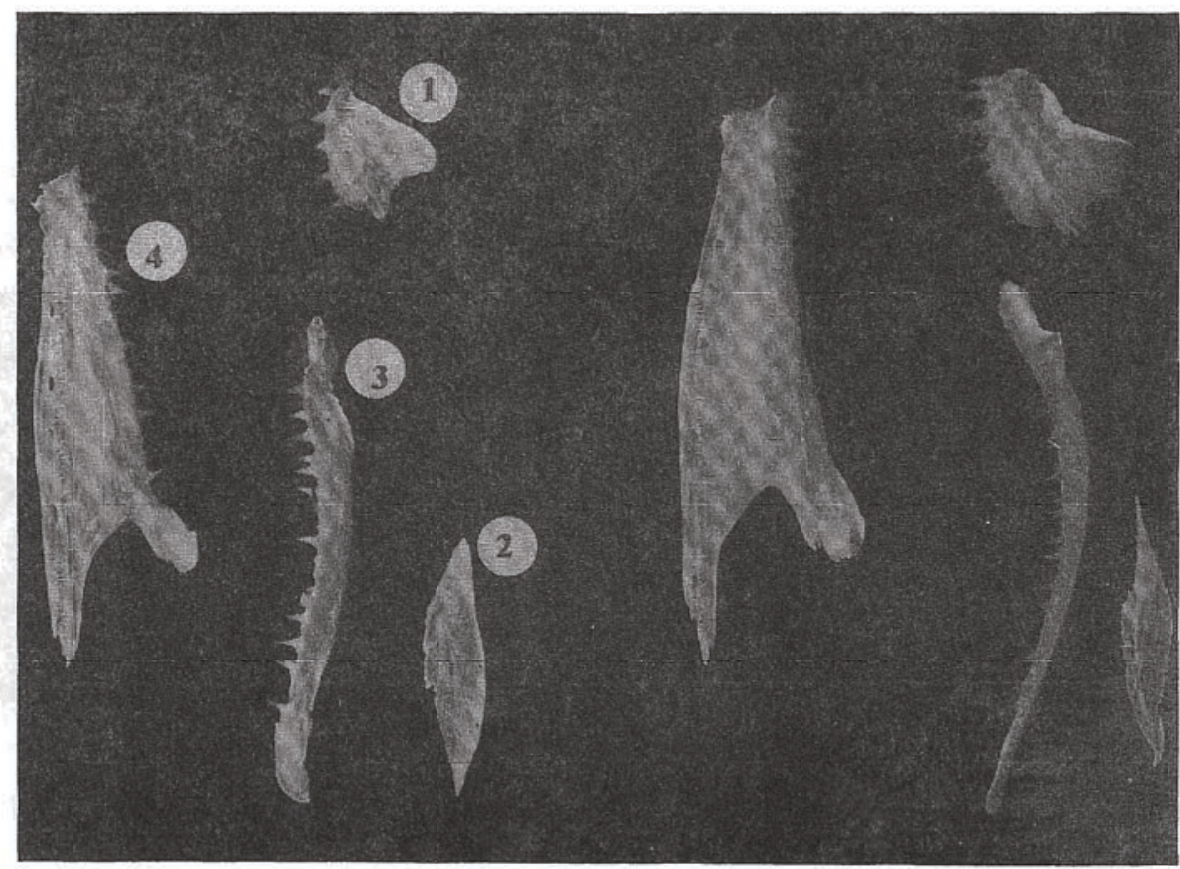

Fig. 4. Some skull bones of Arctic charr (S. alpinus) from the area of Hornsund: 1, premaxilla; 2, supramaxilla; 3, maxilla; 4 , dentary. Male bones to the left; female bones to the right 




Fig. 5. Variability of the vomer in Arctic charr (S. alpinus) from the area of Hornsund. Top: male bones; bottom: female bones
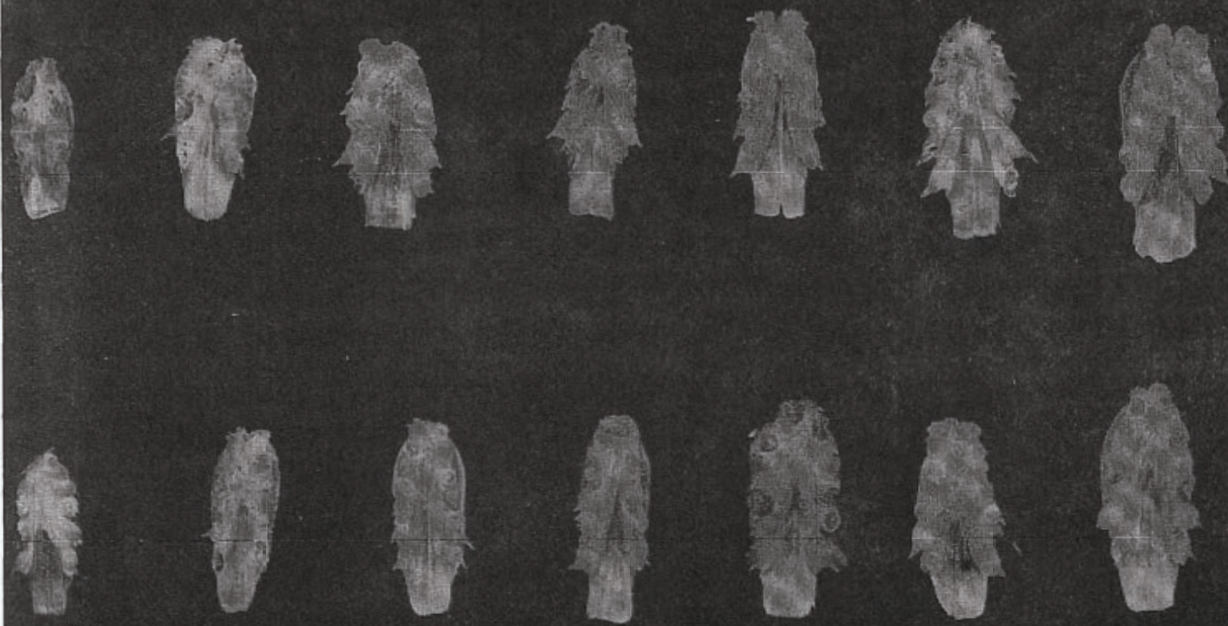

Fig. 6. Variability of the lingual plate in Arctic charr (S. alpinus) from the area of Hornsund. Top: male bones; bottom: female bones 

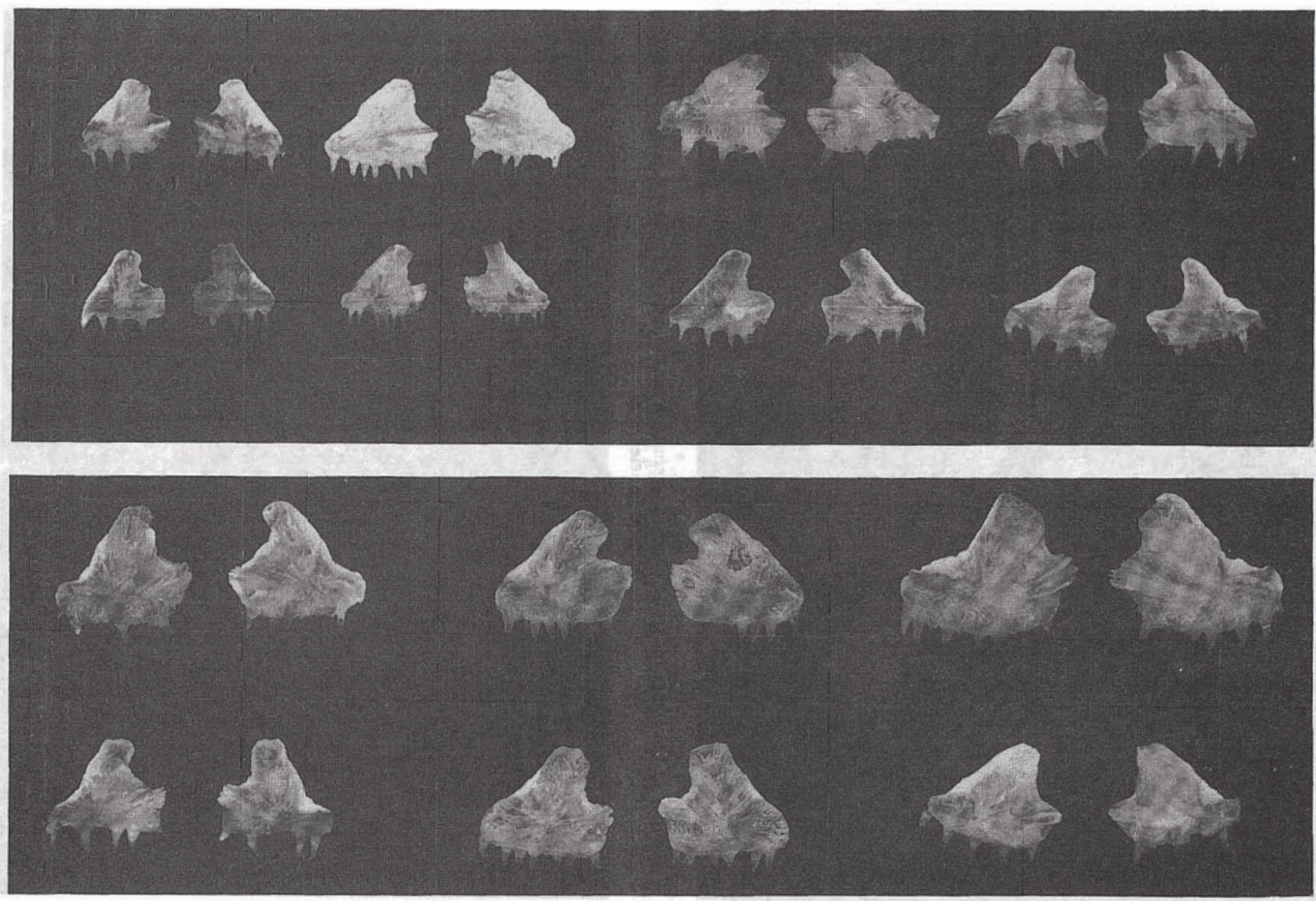

Fig. 7. Variability of the premaxilla in Arctic charr (S. alpinus) from the area of Hornsund. Top: male bones; bottom: female bones 




Fig. 8. Variability of the hyomandibular in Arctic charr (S. alpinus) from the area of Hornsund. Top: male bones; bottom: female bones 


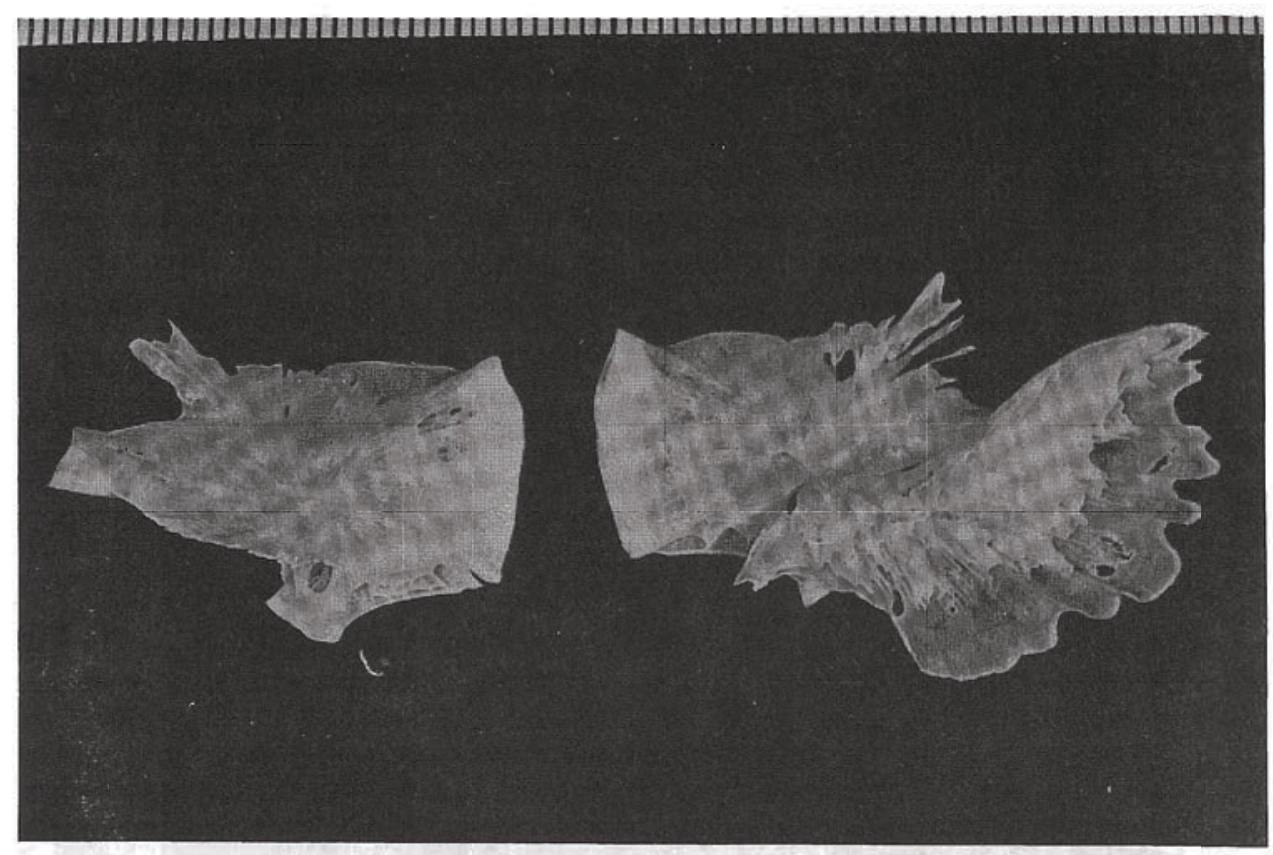

Fig. 9. Malformations in bone structure of $S$. alpinus from the area of Hornsund. Left: hyomandibular from the left hand side of the skull; right: hyomandibular from the right hand side of the skull; both bones accreted to the strongly altered preopercle

S. alpinus of Greenland, while Andrews and Lear (1956) found 63-69 vertebrae in the Arctic charr of the Labrador coast, the mean vertebrae count increasing with latitude. McPhail (1961) and Cavender (1980) report 65-71 and 64-68 (66.5 on the average) vertebrae, respectively, in the Alaskan population.

One individual (a $46.6 \mathrm{~cm}$ long female) was disregarded in calculations due to clear malformations of its backbone (Fig. 2). The backbone consisted of 59 vertebrae only, the main parts of three vertebrae $(16,17,18)$ being elongated and altered. Each of those three vertebrae was formed by the accretion of 2 or 3 vertebrae.

Numerous workers, e.g. Rešetnikov and Savvaitova (1962), Koljušin (1971), and Pičugin (1983) pointed to a considerable variation in osteological characters within a population, this being the case also in S. alpinus in the Hornsund area. As most individuals (39) were caught from Lake Svartvatnet, no comparison between populations from different water bodies could be made. Among the Svartvatnet individuals, however, a high variability in osteological characters was observed.

The appearance and shape of numerous skull bones differed between individuals. The differences were due to sexual dimorphism (Figs 3-4), but variations were found also within sexes. Figs 3-8 show diversity of shapes of selected bones collected from males and females. The variability in size and appearance of the Hornsund Arctic 
charr skull bones is exceptionally high. It is particularly evident in the lingual plate (Fig. 5), vomer (Fig. 6), premaxilla (Fig. 7), and hyomandibular (Fig. 8). The variability may have been in part caused by the extensive range of sizes (total length of 34.0$-60.7 \mathrm{~cm}$ ) and age in the sample.

Some skull bones were malformed. The hyomandibular bone on the right hand side of the skull of a $55.0 \mathrm{~cm}$ long (caudal length) female was accreted to the greatly altered preopercle (Fig. 9).

Backbone malformations in adult fishes living in their native habitats are relatively rare as such individuals are very early eliminated from the population.

\section{REFERENCES}

Andrews C.W., E. Lear, 1956: The biology of Arctic charr (Salvelinus alpinus L.) in Northern Labrador. - J. Fish. Res. Board Canada, 13, $6: 843-860$.

Caveader T.M., 1980: Systematics of Salvelinus from the North Pacific Basin. - In: Balon E.K. (ed.). Charrs, salmonid of the genus Salvelinus. - Dr W. Junk Públ., The Hague : 295-322.

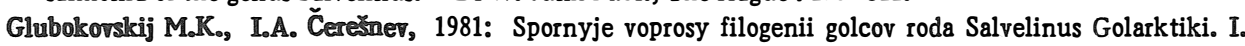
Izučenije prochodnych golcov iz bassejna Vostočno-Sibirskogo Morja. - Vopr. ichtiol., 21, 5 : 771-786.

Koljušet A.J., 1971: Nekotoryje osteologičeskije priznaki golcov i palij (rod Salvelinus) Severo-Zapada SSSR v sviazi s voprosom ich sistematǐ̌eskogo polożenija. - Vopr. ichtiol., 11, 4 : 565-574.

McPhail J.D., 1961: A systematic study of the Salvelinus alpinus complex in North America. - J. Fish. Res. Board Canada, 18, 5: 793-816.

Medredeva K.D., K.A. Sarvaitova, 1980: Intrapopulation and geographic variability of the skull in charrs. In: Balon E.K. (ed.). Charrs, salmonid of the genus Salvelinus. - Dr W. Junk Publ., The Hague : 435-440.

Mina M.V., 1962: Dannyje po ekologii i sistematikie ozernych golcov roda Salvelinus delty ro Leny. - Vopr. ichtiol., $2,2: 230-241$.

Norden C.Ro, 1961: Comparative osteology of representative salmonid fishes, with particular reference to the grayling (Thymallus arcticus) and its phylogeny. - J. Fish. Res. Board Canada, 18, $5: 679-791$.

Picugin MoJ. 1983: Osteologi eskaja charakteristika jużnogo golca roda Salvelinus (Salmonidae) iz populacij riek My i Bolšaja Iska (Amurskij liman). - Vopr. ichtiol., 23, $4: 557-568$.

Quadri S.U., 1974: Taksonomic status of the Salvelinus alpinus complex. - J. Fish. Res. Board Canada, 31, $8: 1355-1361$.

Resetnilsor J.S., KoA. Sతevraitova, 1962: Nekotoryje osobennosti strojenija čerepa i chvostovogo otdela skeleta u golcov roda Salvelinus. - Vopr. ichtiol., $2,3: 434-440$.

Vasileva E.D., 1981: Ozernyj golec Salvelinus alpinus L. iz bassejna reki Zarubicha (k voprosu o golcach i paliach Kolskogo poluostrova). - Vopr. ichtiol., 21, 2 : 232-247.

Translated: Dr. T. Radziejewska 
Andrzej SOBOCIŃSKI, Krzysztof RADZIUN

\section{WSTEQPNE BADANIA OSTEOLOGICZNE GOLCA SALVELINUS ALPINUS (L., 1758) Z REJONU HORNSUNDU (SPITSBERGEN)}

\section{STRESZCZENIE}

W ramach pracy dotyczącej biologii golca, Salvelinus alpinus (L. 1758) z rejonu Hornsundu (Spitsbergen Zach.), wykonano wstępne badania osteologiczne na 48 osobnikach. Na rentgenogramach (Ryc. 1) policzono kręgi. S. alpinus z rejonu Hornsundu ma 63-67 (šr. 64,3) kręgów (Tab. 1). Wstępnie zanalizowano, pod kątem zróżnicowania, wielkošć i kształt kos̊ci czaszki (Ryc. 3-8). Na duże zróżnicowanie wyglądu kości może mieć wpływ, opro̊cz dymorfizmu płciowego, znaczne zrōżnicowanie pröby pod względem długości i wieku. W badanej pröbie zaobserwowano także anomalie w obrębie kręgosłupa (Ryc. 2) oraz kości czaszki (Ryc. 9).

Opracowanie wykonano w ramach C.P.B.P. 03.03. A/5.5./89

Authors' address:

Received: 1991.05 .24

Mgr inż. Andrzej Sobocinonki, dr Krzysztof Radziun

Zakład Anatomii i Embriologii Ryb

Akademia Rolnicza

ul. K. Kro̊lewicza 4

71-550 Szczecin

Polska, Poland 